\title{
Trends in the development of computerization of forensic handwriting examination
}

\author{
IZYUMOV RUSLAN NiKOLAEVICH \\ Department of Forensic Science and Criminalistics \\ Russian State University of Justice, Moscow, Russia
}

\begin{abstract}
Forensic handwriting examination is one of the most complex and controversial types of forensic research, the results of which are often disputed in court. One of the reasons for that is experts' subjectivity. Using quantitative methods and introducing computer technology in the process of handwriting examination can increase its objectivity. Thus, the article analyzes various ways to improve handwriting research, which in the future may increase its objectivity. The author examines the development trends of quantitative methods and the use of computer technology in handwriting examination process.
\end{abstract}

Keywords: judicial handwriting, forensic handwriting examination, computerization, computer technology in the process of handwriting examination

\section{Introduction}

The contemporary era is strongly characterized by the rapidly developing information technology. Scientific and technological progress plays a crucial role in the life of modern society, both on an individual and state level. It is obvious that using computing technology can simplify and improve most human professional activities. One of them is forensic expertise, and in particular forensic handwriting examination. 
Launch of computer technologies and science investigations in handwriting examination occurred in the USSR between the 1960s and the 1970s. The major contributors were Russian criminologist R.M. Lanzman together with mathematicians V.A. Yakubovich and B.N. Kozinets. Further followers of this direction and research of theoretical and practical provisions of this field included scientists such as: A.A. Zhuravel, N.V. Troshko, L.G. Edzhubov, A.Y. Lerner, V.N. Vapnik, I.B. Siroja, A.M. Companets, A.R. Shlyakhov, V.A. Poshkevichus, V.F. Orlova, A.V. Smirnov, N.G. Sakharov, P.V. Bondarenko, N.A. Zamaraeva, and others.

\section{Related works}

Looking back at its history, we can notice that handwriting examination was the first branch of criminalistic examinations where the attempts of using computer technologies took place. However, even then, the aforementioned scientists realized that increasing objectiveness of handwriting examination was a necessity. I believe it is also important today due to a number of reasons.

1. Forensic handwriting examination is still partially subjective. Despite the fact that an expert is bound by a well-established set of rules, his evaluations may not be entirely objective. Some internal and external factors might affect an expert's work, which may lead to a wrong conclusion, which is utterly unacceptable.

2. Current mathematical methods developed for purposes other than handwriting examination may cause some difficulties for experts. Computer technologies can adjust the above methods, making it possible to use them in such examinations.

3. Today, the signature is certainly among the most popular objects of handwriting expertise, as well as identification research of signature - is a very important task during the work on criminal, arbitration, and other cases. Despite the common practice being the use of a traditional method, there are still some rare tasks which cause significant difficulties and require a special approach. The study of simple, concise, and simplified signatures, as well as signatures with letter-free transcription, can be con- 
sidered such a task. The system of general and specific features was created in 1964 for research on overly informative handwriting implementations. The problem is that this system is not appropriate for small and short handwriting objects. That is why science society faced the necessity of developing new handwriting features system with the use of computer technologies.

4. Using computer technologies in other types of criminalistic expertise. For example, the common use of such software and technical complexes as ADIS, Dakto 2000 (NGO Todes, Minsk), Sonda (LLP Pathfinder, Miass), Arsenal (TO papilon, Miass), PTC for the compilation of subjective portraits FRS-2 (MSTU called Bauman's).

All these factors explain the wide interest in implementing computer technologies into handwriting examination. Years ago, Russian criminalistic experts did research which proved the potential of using computer technologies in handwriting examination. This fact stimulates new research. Unfortunately, some authors and scientists note that the developed theoretical and practical statements and programs are not often used in real life. I believe that one of the reasons is the low level of programing knowledge in that time, which lead to bad research results and faulty implementation of computer technologies. Besides, there are also organizational issues: the absence of economic, political, financial, technical, and other resources. There are also individual factors, such as a low motivation level.

Computerizing handwriting examination is a difficult process, consisted of integrating legal and technical knowledge. Research on this issue should be done in a new way, with the use of previous experience and simultaneous attention to the modern circumstances. I am sure that computerization of handwriting examination should be classified as a new concept. Besides, a more systemic approach is necessary. The basis for this new conception is scientific research, results of which form theoretical and methodological foundations for implementing computer tools into the handwriting examination practice. To my mind, the priority of computerization is identifying the general direction as well as describing useful methods and operations. 


\section{Conclusions}

Modern technologies create opportunities to develop handwriting examination. The analysis of modern studies with common topics suggests that the next decade will be a time of improvements in this branch of criminalistic examination. Computer technologies will lead to the development of automated databases, which will help solve unique cases. This is going to be the time of computers recognizing handwritten texts and signatures, the development of separate automated methods, the integration of automated technical tools into the process of handwriting expertise, as well as the development and study of new trends such as the biometric signature.

I managed to analyze key historical aspects of handwriting examination computerization in Russia. Specific programs and tools are not popular among experts. There are no universal and general methods or complexes. Unfortunately, there are also theoretical and methodological gaps in computerization of handwriting examination. That is why continuing the research is still necessary.

\section{References}

Averyanova T.V., Sudebnaya ekspertiza: Kurs obshchei teorii, Moskva 2009.

Cieśla R., Bellucco S., Pugnaloni M., "The biometric signature in Europe the new profession of forensic grafobiometristslaws, protocols, and methodology", Teoriya i praktika sudebnoi ekspertizi v sovremennih usloviyah. Materiali VII Mejdunarodnoi nauchno-prakticheskoi konferencii, Moscow 17-18 January 2019.

Huber R., Headrick A., Handwriting identification: Facts and fundamentals, Boca Raton, FL 1999.

Koshmanov P.M. Koshmanov M.P., "Etapi i osnovnie napravleniya vnedreniya kompyuternih tehnologii $\mathrm{v}$ sudebnoe pocherkovedenie i pocherkovedcheskuyu ekspertizu", Ekspert kriminalist 2008, no. 3.

Kozinec B.N., Lancman R.M., Yakubovich V.A., "Kriminalisticheskaya ekspertiza blizkih pocherkov pri pomoschi elektronno vichislitelnih mashin", Doklady Akademii Nauk SSSR (Reports of the Academy of Sciences of the USSR) 167, 1966, no. 5, pp. 1008-1011.

Smirnov A.V., Programma «OKOl» dlya issledovaniya kratkih i prostih pocherkovih obektov: Teoriya i praktika sudebnoi ekspertizi, Moskva 2006. 
Trushakova N.A., "Sudebno pocherkovedcheskaya ekspertiza na sovremennom etape: Problemnie voprosi i puti ih resheniya", Vestnik Moskovskogo universiteta MVD Rossii $\backslash 4,2018$.

Ustinov V.V., Modelnie metodi sudebno pocherkovedcheskogo issledovaniya problemi i tendencii razvitiya, Moskva 2011. 